\title{
Scenarios for Bridging up the Productivity Gaps along the Romanian Vegetable Supply Chain
}

\author{
Cornelia ALBOIU ${ }^{1)}$ \\ 1) Department of Agricultural Markets, Institute of Agricultural Economics, Calea 13 Septembrie nr. 13, \\ sector 5, 050711, Bucharest, Romania. \\ ${ }^{*}$ Corresponding author, e-mail: coraalboiu@yahoo.com
}

Bulletin UASVM Horticulture 71(2) / 2014

Print ISSN 1843-5254, Electronic ISSN 1843-5394

DOI:10.15835/buasvmcn-hort:10582

\begin{abstract}
In recent years, the productivity of agri-food sector has become again a subject of interest due global challenges caused by increasing food demand in new emerging countries, non-food uses of agricultural production for biofuels, and the impact of technology and innovation on productivity in agriculture, including the fast development of large retail chains, which can lead to growth and poverty alleviation in both rural and urban areas. Interest in this topic is marked mainly by higher volatily prices and production of vegetables and the current incapacity of the Romanian vegetable producers to fully cover the domestic demand. The aim of this paper is the analysis of productivity in primary production and processing sector level, using as methodology specific indicators and scenarios to bridge up production gaps so that the demand is fully covered by the domestic production. The results show that in case of a realistic scenario, taking into account the growth rates of the area cultivated with vegetables under greenhouses and plastic tunnels by over $50 \%$ in the last five years, this goal is possible. However, the scenario might become achievable only in the case that the organization level increases significantly from about $1 \%$ at present to about $35 \%$, the average organization level in the European Uninon.
\end{abstract}

Keywords: productivity gaps, scenarios, vegetable supply chain

\section{INTRODUCTION}

In the EU countries, agricultural productivity is again a topic of interest having in view several recent phenomena such as the increase of agricultural prices and their volatility, fragmentation of markets and last but not the least a significant decrease in consumer income under the current economic crisis. In this context, due to significant agricultural resources, Romania may return to play an important role in European and global agricultural market that would allow it to recover the productivity gaps compared to the productivity of other EU countries taking into account the new Common Agricultural Policy and the new Rural Development Program 2014-2020. The Romanian vegetable sector is characterized by high fragmentation and high production and prices volatility. The vegetable production sector is still dominated by a high volatility of price and productivity mainly in the primary production sector, this being an important research topic.
Globalization has also an impact on the evolution of production and yields considering the contribution of technological progress and innovation in the vegetable chain.

Recent studies present a full picture of the impact of globalization on small producers in developing countries and countries in transition such as those from the Central and Eastern Europe (Codron et al., 2004, Reardon et al., 2009, Swinnen, 2007). These studies highlight the importance of market imperfections both in the production and marketing and the agricultural input markets, hindering farmers' access to modern marketing chains.

After the collapse of vertically integrated supply chains in the first years of transition as a result of the privatization and restructuring, vertical coordination restarted to slowly rebuild its presence due to rising standards required by multinationals and imperfect character of the markets (Gow and Swinnen, 1998, 2001). Hobbs 
(2006) points out that in addition to the historical problem of prices, farmers' low productivity and profits result in farmers' need to adapt to major changes in the system dynamics that require deep institutional changes and decisions to invest in higher yields.

Within the institutions, an important role it is played by the collective actions and in Romania's case in particular, the establishment of producer groups and organizations, might contribute to increasing participation of local vegetable producers in the major supply chains with the purpose to increase productivity, quality of production and farmers' bargaining power. However, in the case of collective actions, Bardhan (1989) points out an important negative phenomenon, namely the opportunism which practically limits the development of these types of institutions whose purpose is to create mutual benefits. It is anticipated that collective actions within institutional and organizational approach could help to reduce transaction costs and increase productivity by using the same suppliers of inputs, selected seeds and unitary technology. While competition in the retail chains stimulate changes in the type of retail formats with a trend of concentration and consolidation among them, in case of vegetables producers and the support offered to various forms of association collective action it might be noticed a certain degree of imbalance. This raises a major challenge for small vegetables producers whether in Romania or elsewhere in Europe and beyond, namely how to become part of modern marketing channels, where the modern retail chains usually coordinate other actors (dell'Aquila et all, 2011).

Regarding the organization of the vegetable sector in Romania, the figures show an average a low organization level far from the target set under the Common Market Organization in the vegetable sector. According to an Agrosynergie report (2008), in 2006 the degree of organization was $34 \%$ in the EU-25 and $35 \%$ in the EU-15. When Bulgaria and Romania joined the EU, the degree of organization of the sector has greatly decreased due to a low organization rate, below $1 \%$ in the two countries (Jacquin, 2010). The degree of organization is very heterogeneous across countries: it increased by $80 \%$ only in Netherlands, Belgium and Ireland. A special case is Netherlands, which has a degree of organization of more than $100 \%$ due to the transnational producer organization. The organization level is different in the old member states and the new member states. The poor organization of the sector is reflected in low productivity, mainly in the production of raw products, since it does not allow farmers to purchase or use selected seeds with high potential yields and to apply modern technologies. The area under vegetables represented $3.18 \%$ of total cultivated arable land in 2012. At the EU level, the weight is approximately similar, but in Romania, the demand is still not met by the domestic resources.

\section{MATERIALS AND METHODS}

The objective of the paper is the evaluation of vegetable supply chain from the perspective of bridging up the productivity gaps between Romania and other European Union countries along the supply chain. The objective is generous, given the vegetables supply chain characteristics, namely demand and supply atomization, seasonality, vegetables cultivation tradition, and an unorganized marketing system; at the same time, the demand for vegetable products is an ongoing, while demand is seasonal. This leads to greater variability of prices and yields. In this context, the objective of this paper is to assess the vegetable chain in terms of productivity gaps. To achieve the objective of the paper, certain productivity indicators are used, as well as comparisons with other European Union member states.

The main indicators used in the primary production are the following:

- cultivated area, production and yields per hectare in Romania and comparisons with EU member states. These indicators were chosen because they allow comparisons between Romania and EU countries and also because they are used in the scenario constructed in order to cover productivity gaps.

In the processing sector:

- Processing capacity

- Coverage of processing capacity

For consumers: annual consumption of vegetables per capita and total consumption of vegetables.

Based on these indicators, a scenario is constructed, with the base year 2012, and several hypotheses are considered based on the analysis of the indicators listed above, namely: cultivated 
area, average yields, human consumption and raw products consumption for processing. The scenario is developed for tomatoes, as this product has the highest share regarding the cultivated area but it records the highest volatility in terms of production and prices (Alboiu, 2012).

\section{RESULTS AND DISCUSSION Vegetable productivity indicators in the primary sector}

According to data provided by the Integrated Administration Control System in Agriculture in Romania, the vegetable farms under 3 hectares prevail, $85 \%$ of them being managed by individual farmers. The degree of market fragmentation and dispersion of cultivated land following land restitution as a result of the Land Law no. 18/1991 and the followings laws create significant limitations regarding the adoption of new technologies (agricultural works, processing and marketing structure, updating farmers' skills) and contributes to increases in production costs and transaction costs. Due to the lack of experience in the use of insurance schemes and lack of confidence in the system and the transaction costs involved, any adverse climatic event, disease or pest infestation create direct losses to vegetable producers. At the same time, the existence of a large number of farmers who produce for their own consumption but sell a part of the production either at the farm gate directly or through intermediaries, does not allow for a clear distinction between commercial and subsistence farms, and consequently hinder the adoption of appropriate fiscal policies. All these factors have a direct impact on farmers' income, price fluctuations, market orientation of the sector and its productivity.

Growing vegetables in Romania is an activity with a long tradition. Taking into account the cultivated area, Romania ranks the 5th among countries producing vegetables from the European Union (Fig. 1), and 6th in terms of the area under orchards.

As regards the cultivated areas in Romania, an extremely interesting and important phenomenon that could be noticed in recent years is the increase of land areas cultivated under greenhouses and plastic tunnels. Basically, in 2012 compared to 2007, the areas under vegetables in greenhouses and plastic tunnels increased by $50 \%$ and $24 \%$ as compared to the $2007 / 2011$ average (Tab. 1).

Total vegetables production slightly increased in the analysed period. With the increase of cultivated areas under greenhouses and plastic tunnels, it must be signal out the increase of vegetables production grown in greenhouses and plastic tunnels, the production increasing by $44 \%$ in 2012 compared to 2007 and by $9 \%$ compared to the average years $2007 / 2011$ (Tab. 2).

Compared to other European Union member states in terms of the obtaiend vegetables and melons production, Romania ranks the 7 th after countries such as Italy, Spain, Poland, France and the Netherlands (tab.3).

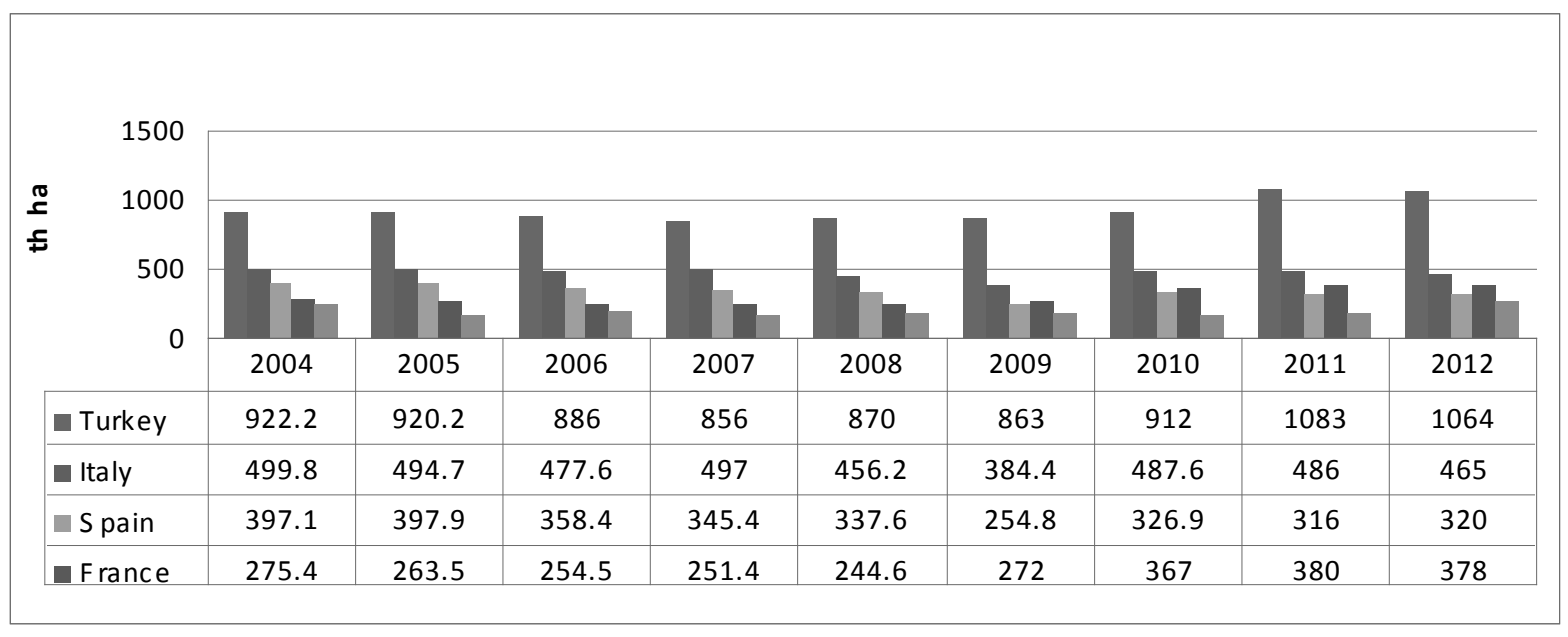

Source: Eurostat

Fig. 1. Vegetables cultivated areas in Romania and other EU or non-EU Member States 
Tab. 1. Cultivated areas by area categories

\begin{tabular}{|c|c|c|c|c|c|c|c|c|}
\hline & 2007 & 2008 & 2009 & 2010 & 2011 & 2012 & \begin{tabular}{|l|} 
Variation 2012/Avg \\
\end{tabular} & \begin{tabular}{|l|} 
Variation \\
$2012 / 2007$ \\
\end{tabular} \\
\hline Total (no) & 241220 & 258851 & 257752 & 254293 & 254549 & 249282 & $-2 \%$ & $0 \%$ \\
\hline \begin{tabular}{|l|} 
out of: Individual households \\
\end{tabular} & $95 \%$ & $96 \%$ & $96 \%$ & $96 \%$ & $95 \%$ & $95 \%$ & & \\
\hline Field vegetables (ha) & 156056 & 167136 & 165865 & 159364 & 161355 & 157622 & $-3 \%$ & $1 \%$ \\
\hline Individual households & $93 \%$ & $94 \%$ & $95 \%$ & $93 \%$ & $92 \%$ & $93 \%$ & & \\
\hline $\begin{array}{l}\text { Vegetables in greenhouses } \\
\text { and plastic tunels (ha) }\end{array}$ & 2170 & 2415 & 2481 & 2545 & 3506 & 3275 & $24 \%$ & $50 \%$ \\
\hline out of: Individual households & $84 \%$ & $87 \%$ & $90 \%$ & $89 \%$ & $87 \%$ & $92 \%$ & & \\
\hline $\begin{array}{l}\text { Fresh vegetables in family } \\
\text { gardens (ha) }\end{array}$ & 82994 & 89300 & 89406 & 92384 & 89688 & 88385 & $-1 \%$ & $0 \%$ \\
\hline Individual households & $100 \%$ & $100 \%$ & $100 \%$ & $100 \%$ & $100 \%$ & $100 \%$ & & \\
\hline
\end{tabular}

Source: NIS, tempo on line 2013

Tab. 2. Vegetable production by categories of areas

\begin{tabular}{|l|r|r|r|r|r|r|r|r|}
\hline & 2007 & 2008 & 2009 & 2010 & 2011 & 2012 & $\begin{array}{l}\text { Variation } \\
\text { '12/ } \\
\text { avg'07-'11 }\end{array}$ & $\begin{array}{l}\text { Variation } \\
2012 / 2007\end{array}$ \\
\hline $\begin{array}{l}\text { Field vegetables (tons) } \\
\text { of which individual } \\
\text { households }\end{array}$ & 2082095 & 2580433 & 2664055 & 2388781 & 2753054 & 2373957 & $-14 \%$ & $14 \%$ \\
\hline $\begin{array}{l}\text { Vegetables in plastic } \\
\text { tunnels (tons) }\end{array}$ & $66 \%$ & $67 \%$ & $67 \%$ & $61 \%$ & $65 \%$ & $66 \%$ & & \\
\hline $\begin{array}{l}\text { of which individual } \\
\text { households }\end{array}$ & $2 \%$ & $2 \%$ & $2 \%$ & $2 \%$ & $3 \%$ & $3 \%$ & & \\
\hline $\begin{array}{l}\text { Fresh vegetables in } \\
\text { families garden (tons) }\end{array}$ & 965620 & 1154138 & 1161754 & 1384389 & 1298616 & 1063201 & $-10 \%$ & $10 \%$ \\
\hline $\begin{array}{l}\text { of which individual } \\
\text { households }\end{array}$ & $32 \%$ & $31 \%$ & $31 \%$ & $37 \%$ & $33 \%$ & $32 \%$ & & \\
\hline
\end{tabular}

Source: NIS, tempo on line, 2013

Tab. 3. Vegetables production in Romania, compared to the EU, 2012 (thousand tons)

\begin{tabular}{lccc}
\hline & Tomatoes & Carrots & Onions \\
\hline EU-28 & 15855 & 5185 & 5977 \\
\hline Spain & 4074 & 370 & 1170 \\
\hline France & 764 & 541 & 412 \\
\hline Italy & 5962 & 543 & 414 \\
\hline Netherlands & 805 & 511 & 1353 \\
\hline Poland & 759 & 835 & 642 \\
\hline Portugal & 1393 & 75 & 48 \\
\hline Romania & 423 & 111 & 214 \\
\hline Bulgaria & 94 & 10 & 10 \\
\hline
\end{tabular}

Source: Eurostat, 2013

Total vegetables production in the EU 28 was estimated at 15.8 million tons of tomatoes in 2012, of which about two-thirds comes from Italy and Spain. While tomato production fell significantly in Italy (from 7.5 million tons in 2000 to 6 million tons in 2012, production in Spain was much more stable, around 4 million tons. Romania with 423 000 tons tomato remains a very important player.
Regarding other vegetables, in the EU-28, $5.2 \mathrm{mi}-$ llion tons of carrots and 6 million tons of onions were produced in 2012. Netherlands and Spain are the main onion producers in the EU, together accounting for over $42 \%$ of onion production in 2012 in the European Union, Romania occupying $7^{\text {th }}$ position. 


\section{Vegetable yields per hectare}

The evolution of the average production is highly volatile, mainly due to weather conditions variations. In addition to volatility due to changes in weather conditions, in recent years, the shortage of labor supply added up, as well as other difficulties, including institutional ones (the issue of producer certificate); all these led to insufficient income for farmers to make capital investments, to buy modern equipment and technology and to use quality inputs able to contribute to increased productivity. As the scenario presented in this paper refers to tomatoes, a few data on the cultivated areas, total production and average yields per hectare for this product are presented. This product was selected because it represents the main vegetable that is cultivated in Romania (Alboiu, 2012) and at the same time the fluctuations of productions and yields per hectare are the highest compared to other types of vegetables, while the tomato import is quite significant (more than $50 \%$ of total imports of vegetables). The table below presents the evolution of areas cultivated with tomatoes and the dynamics 2012 compared to 2011 in Romania and in other EU member states, as well as the 2012 variation compared to the 2007-2011 average (Tab. 4).

For example, in the case of tomato production, a strong variability can be noticed with minimum yields in 2007, and a maximum yield of 22 tons/ hectare in the year 2011. The average tomato yield at EU level is 60 tons/hectare, and the average cabbage yield 28 tons/hectare (FAO database, 2013). On a comparative basis, tomato yields in Romania are almost 3-4 times lower. Following the integration into the EU structures, the chain of vegetables seems the most affected, on one hand due to uncontrolled imports and on the other

Tab. 4. Area cultivated with tomatoes compared to EU level (1000 ha)

\begin{tabular}{lrrrrrrccc}
\hline & 2007 & 2008 & 2009 & 2010 & 2011 & 2012 & $\begin{array}{c}2007-2011 \\
\text { average }\end{array}$ & $\begin{array}{c}\text { 2012 vs 07- } \\
\text { 11 variation }\end{array}$ & $\begin{array}{c}\text { 2012/ } \\
\text { 2011 variation }\end{array}$ \\
\hline Italy & 125.3 & 115.5 & 117.1 & 118.8 & 103.8 & 103.8 & 114.1 & $-9.00 \%$ & $0 \%$ \\
\hline Spain & 53.3 & 55.3 & 62.1 & 59.3 & 49.9 & 48.8 & 54.8 & $10.90 \%$ & $-2 \%$ \\
\hline Romania & 26.1 & 30.3 & 27.7 & 28.5 & 29.3 & 27.8 & 28.3 & $-1.70 \%$ & $-5 \%$ \\
\hline Greece & 26.8 & 25 & 25 & 24.2 & 19.7 & 19.7 & $23.40 \%$ & $-15.80 \%$ & $0 \%$ \\
\hline Portugal & 14.8 & 14.3 & 16.8 & 16.6 & 16.7 & 15.4 & 15.8 & $-2.40 \%$ & $-8 \%$ \\
\hline Poland & 11.5 & 10.5 & 11.1 & 14.5 & 11.7 & 1.7 & 11.8 & $-1.10 \%$ & $0 \%$ \\
\hline Bulgaria & 4.8 & 3.5 & 3 & 3.5 & 4.3 & 3.4 & 3.7 & $-9.30 \%$ & $-21 \%$ \\
\hline France & 3.9 & 4.1 & 4.5 & 5.9 & 6 & 5.2 & 4.9 & $5.30 \%$ & $-13 \%$ \\
\hline
\end{tabular}

Source: Eurostat

Tab. 5. Tomato production in several EU countries (1000 tons)

\begin{tabular}{|c|c|c|c|c|c|c|c|c|c|}
\hline & 2007 & 2008 & 2009 & 2010 & 2011 & 2012 & $\begin{array}{c}\text { Average } \\
2007-2011\end{array}$ & $\begin{array}{l}\text { Variation } \\
2012 \text { vs } \\
07-2011\end{array}$ & $\begin{array}{c}\text { Variation } \\
2012 / 2011\end{array}$ \\
\hline Italy & $6.528,0$ & $5.982,1$ & $6.382,7$ & $6.024,8$ & $5.962,0$ & $5592^{\circ}$ & $6.175,8$ & $-9 \%$ & $-6 \%$ \\
\hline Spain & $4.081,5$ & $3.847,8$ & $4.749,2$ & $4.312,7$ & $3.821,0$ & $4.073,7$ & $4.162,5$ & $-2 \%$ & $7 \%$ \\
\hline Greece & $1.423,9$ & $1.338,6$ & $1.350^{\circ}$ & $1.406,2$ & $1.170,0$ & $1.169,9^{\circ}$ & $1.337,7$ & $-13 \%$ & $0 \%$ \\
\hline Portugal & $1.236,0$ & $1.147,6$ & $1.346,1$ & $1.406,1$ & $1.245,0$ & $1.392,7$ & $1.276,2$ & $9 \%$ & $12 \%$ \\
\hline France & 679,6 & 714,6 & $725,0^{\circ}$ & 808,4 & 845,0 & 763,5 & 754,5 & $1 \%$ & $-10 \%$ \\
\hline Romania & 407,1 & 536,3 & 470,9 & 414,5 & 590,1 & 423,4 & 483,8 & $-12 \%$ & $-28 \%$ \\
\hline Poland & 277,4 & 257,4 & 265,3 & $\left.225^{\circ}\right)$ & $\left.273^{\circ}\right)$ & $\left.261,0^{\circ}\right)$ & 259,6 & $1 \%$ & $-4 \%$ \\
\hline Bulgaria & 133,2 & 134,1 & 104,2 & 114,6 & 103,1 & 94,0 & 117,8 & $-20 \%$ & $-9 \%$ \\
\hline TOTAL EU-27 & $16.279,0$ & 15.497 & 16.981 & 16.248 & 15.597 & $15.267,0$ & 16.120 & $-5 \%$ & $-2 \%$ \\
\hline
\end{tabular}

Source: Eurostat; ${ }^{\circ} \mathrm{FAO}$ 
hand due to farmers' impossibility or incapacity to maintain stable contractual relations along the chain. This adds to farmers' incapacity to establish producer groups because of the lack of trust or desire to cooperate.

There is a strong volatility of tomato yields/ hectare, Romania having the highest yearly volatility in 2012 versus 2011, compared to other EU member States. Also, Romania had the lowest yields compared to countries like Spain or Italy, where yields can reach $50-60$ or even 70 tons per hectare, in the case of Spain, for instance (Tab. 6). Unfortunately, Romania also has extremely low yields compared to countries like Bulgaria or Poland, where a maximum yield was reached in 2008 , i.e. 38.3 tons/ha in Bulgaria and 24.5 tons/ ha in Poland, while in Romania the maximum yield per hectare was in 2011, i.e. 20.1 tons/ha.

\section{The processing sector indicators}

The total processing capacity is of 237107 tons/year. Most of the processing units have implemented HACCP system which allow them to access the EU market but also international markets. Thus, approximately $60 \%$ of the fruit canned vegetables are intended for retail chains in Romania and the European Union and non-EU member states such as Israel, Canada and the USA. From a production of $3,864,000$ tons vegetables, 100,000 tons (or $2.6 \%$ ) is for processing. Usually, farmers deliver directly to these industries, without intermediaries and traders. For tomatoes, the largest share of domestic consumption is represented by human consumption (63\%). The amount of tomatoes for processing increased in 2009 by $20.5 \%$ over the previous year, a trend recorded in 2010 and 2011.

The consumption indicatators and evolution

Although the analysis in this paper is made for the period 2007-2012, due the fact that in 2004 Romania recorded the highest level of consumption, the analysis is extended to this year, due the fact that in the scenario construction it is important to take into consideration the maximum level of human consumption.

Tab. 6. The evolution of tomato yields in several EU countries (tons/ha)

\begin{tabular}{lccccccccc}
\hline & 2007 & 2008 & 2009 & 2010 & 2011 & 2012 & $\begin{array}{c}2007-2011 \\
\text { average }\end{array}$ & $\begin{array}{c}2012 / \\
07-11 \\
\text { variation }\end{array}$ & $\begin{array}{c}2012 / 2011 \\
\text { variation }\end{array}$ \\
\hline Italy & 52.1 & 51,8 & 54,5 & 50.7 & 57.4 & 53.9 & 53.4 & $1.10 \%$ & $-6 \%$ \\
\hline Spain & 76.6 & 69.6 & 76.5 & 72.7 & 76.6 & 83.5 & 75.9 & $12.20 \%$ & $9 \%$ \\
\hline Romania & 15.6 & 17.7 & 17.0 & 14.5 & 20.1 & 15.2 & 16.7 & $-10.4 \%$ & $-24 \%$ \\
\hline Greece & 53.1 & 53.5 & 54.0 & 58.1 & 59.4 & 59.4 & 55.6 & $6.80 \%$ & $0 \%$ \\
\hline Portugal & 83.5 & 80.3 & 80.1 & 84.7 & 74.6 & 90.4 & 80.6 & $12.20 \%$ & $22 \%$ \\
\hline Poland & 24.1 & 24.5 & 23.9 & 15.5 & 23.3 & 22.3 & 22.3 & $0.10 \%$ & $-4 \%$ \\
\hline Bulgaria & 27.8 & 38.3 & 34.7 & 32.7 & 24.0 & 27.6 & 30.9 & $-12.30 \%$ & $15 \%$ \\
\hline France & 174.3 & 174.3 & 161.1 & 137.0 & 140.8 & 146.8 & 155.7 & $-6.70 \%$ & $4 \%$ \\
\hline
\end{tabular}

Source: Eurostat. 2013

Tab. 7. Evolution of vegetables consumption per capita and total consumption

\begin{tabular}{lcccccccc}
\hline & 2004 & 2005 & 2006 & 2007 & 2008 & 2009 & 2010 & 2011 \\
\hline $\begin{array}{l}\text { Yearly average consumption } \\
\text { Kg/capita }\end{array}$ & 183.3 & 162.6 & 163 & 165.1 & 151.8 & 141.9 & 146 & 153 \\
\hline $\begin{array}{l}\text { Total vegetable consumption } \\
\text { (Th tons) }\end{array}$ & 3972 & 3516 & 3920 & 3533 & 3263.4 & 3030.2 & 3738 & 3865 \\
\hline $\begin{array}{l}\text { Total tomato consumption } \\
\text { (th tons) }\end{array}$ & 834.12 & 738.36 & 823.2 & 741.93 & 685.314 & 636.342 & 811 & 777 \\
\hline
\end{tabular}

Source: NIS, Food balance sheets, 2013 
The data from the table above reveal that in the last period the average consumption of vegetables per capita oscillated around $170 \mathrm{~kg}$ per year, in the context of a $10 \%$ growth rate. Considering that Romania's population totals about 21 million inhabitants, the necessary yearly quantity of vegetables would be 3850 thousand tons and this can be covered from the domestic production. At the same time, the tomato consumption represents about $21 \%$ of the total consumption of vegetables and the total tomato consumption would be about 834.12 thousand tons. These figures are further used in the scenarios proposed below.

New opportunities and scenarios for bridging up the productivity gaps along the chain

The positive evolution of the areas of vegetables under greenhouses and plastic tunnels reveals the growth and development potential throughout the chain if accompanied by an adequate organization. Despite certain competitive advantages the vegetable sector still features a high fragmentation level, using obsolete production methods which add to the producers' poor organization level. The trade with vegetables is characterized by a chaotic distribution and an inefficient logistic system and most often a low production quality. After more than 7 years of implementing certain EU standards for production and trade, very many of these with EU funds Romania still needs significant investments for increasing the sector productivity and bridging the gaps between Romania and the EU.

With a total fruit and vegetables consumption of 3.8 mil. $t$ in 2011 (10\% yearly growth rate), the Romanian market has very great opportunities for narrowing the gaps compared to the EU and for domestic productivity increase. At the same time, the consumers become increasingly careful and new consumption tendencies emerged. The productivity growth opportunity is given by the modification of food consumption patterns, with consumers' orientation towards fresh vegetables such as tomatoes, peppers, onions, cabbages, frozen vegetables inclusively. At the same time, new opportunities exist for increasing the cultivated areas under greenhouses and plastic tunnels, as well as for the processing industry, based on the EU finance programs, which means procurement of new technologies (storage facilities, sorting lines) and new production methods (selected seeds, drip irrigation systems).
Unfortunately, the chain operation is still under question as the role of collective actions is still very low. At present, in Romania, there are only 24 producer groups with preliminary recognition and a producer organization (Hortifruct) plus other three organizations recognized in 2013. Initially, in the year 2008, 45 producer groups in the sector of fruit and vegetables had been preliminarily recognized, but in the year 2011 their licenses were withdrawn and at present only 24 groups remained (Alboiu, 2012). Many farmers are not able to establish producer groups or to participate to association forms because of their lack of trust or desire to cooperate. At the same time, the National Rural Development Program has a very low absorption of EU funds for the measure targeting setting up producer groups (Measure 142) i.e. 30\% and the number of applicants is extremely low. Due to the volatility of vegetable prices, the small producers may breach the contract. This attitude hinder the good operation of the producer group, in the sense that the group is no longer able to sell $75 \%$ of the members' production on contractual basis and the development plan initiated under the Operational Program can no longer be respected with negative consequences upon the investments made by the group and upon its preliminary recognition.

\section{Current context of the scenario}

Although the production of vegetables had an increasing trend, the obtained yields do not reflect the true potential. The main causes of this situation are the following:

- most vegetable farms, about $90 \%$ have areas smaller than 3 ha, and these farms are managed by individual natural persons;

- these farms have a limited access to the modern production and harvesting means;

- high land fragmentation and fragmentation along the entire chain;

- large abandoned protected areas and/or built up according to obsolete technologies;

-increase in frequency of extreme weather conditions with a negative impact upon production; - low average yields/hectare.

In spite of these, there is a good potential provided by increasing yields as a result of cultivated areas under greenhouses and plastic tunnels. The main vegetable for which a productivity gap 
bridging scenario is presented, is represented by tomatoes, because this is the product with the highest production volatility and with the highest share in total imports, which also determines significant fluctuations in covering the needs of processing companies with raw materials.

\section{Description of scenario hypotheses}

With all the limitations described in the previous section. the analysis presented in this paper reveals that a constant increase of cultivated areas under greenhouses and plastic tunnels was noticed in the last 5 years. Hence the following hypotheses can be established:

The base year when constructing the scenario is the year 2012

An increase of areas cultivated with vegetables under greenhouses and plastic tunnels by $20 \%$, $40 \%, 50 \%, 70 \%$ and $90 \%$ is envisaged on a 7 -year period beginning with 2014 based on the increases which took place in period 2007-2012

It is assumed an increase of yields per hectare for the field tomatoes by 23 tons/ha. which is an absolutely realistic hypothesis if average yields from countries such as Bulgaria are taking into consideration (see Tab. 6) and an average yield of 36 ton/ha for the areas under vegetables in greenhouses and plastic tunnels

On the basis of the above-presented analysis, it is proposed an increase of human consumption by $10 \%$, so that the total consumption should reach 835 thousand tons, i.e. about $185 \mathrm{~kg} /$ capita

It is assumed that the coverage of the raw products needs for agro-processing from the domestic production starting from the current situation in which the coverage degree is under $40 \%$

In constructing the scenario it was started from the human consumption evolution (Tab.7) on the basis of the hypotheses presented above.

The proposed scenario has in view that by the year 2021, Romania can fully cover the tomato needs both for human consumption and for processing. At the same time, a 7.5 times increase of the storage capacity is foreseen which would enable a much better operation of the chain. Practically, by maintaining the areas cultivated in the field almost constant and by the constant increase of areas cultivated with tomatoes under greenhouses and plastic tunnels by $50 \%$ by the year 2017 and $90 \%$ by the year 2021, together with an increase of yields according to the already described hypotheses, the consumption needs can

Tab. 8. Scenario regarding the evolution of production, cultivated areas, human consumption, processing

\begin{tabular}{|c|c|c|c|c|c|c|}
\hline & 2012 & 2014 & 2015 & 2017 & 2019 & 2021 \\
\hline Scenarios \% & $\begin{array}{l}\text { Base } \\
\text { vear }\end{array}$ & $20 \%$ & $40 \%$ & $50 \%$ & $70 \%$ & $90 \%$ \\
\hline Area (th ha) & 47.7 & 47 & 48 & 48 & 48 & 48 \\
\hline Average yield (tons) & 15.4 & 16 & 17 & 18 & 20 & 23 \\
\hline Total production & 734.5 & 752 & 816 & 864 & 960 & 1104 \\
\hline $\begin{array}{l}\text { Area under greenhouses and } \\
\text { plastic tunnels (hectares) }\end{array}$ & 589 & 706 & 800.8 & 989.4 & 1281.58 & 1742.422 \\
\hline $\begin{array}{l}\text { Average yield in greenhouses and } \\
\text { plastic tunnels (tons) }\end{array}$ & 25 & 26 & 26 & 28 & 35 & 36 \\
\hline $\begin{array}{l}\text { Total production plastic tunnels } \\
\text { (thousand tons) }\end{array}$ & 15 & 18.3 & 23.8 & 27.7 & 44.8 & 64 \\
\hline Human consumption (th tons) & 811 & 820 & 825 & 830 & 832 & 835 \\
\hline Processing (th tons) & 134 & 160.8 & 159.29 & 208.4 & 347 & 333 \\
\hline Coverage degree & $76.4 \%$ & $77 \%$ & $86 \%$ & $87 \%$ & $92 \%$ & $100 \%$ \\
\hline $\begin{array}{l}\text { Raw material storage capacity at } \\
\text { present (th tons) }\end{array}$ & 41.94 & 50.3 & 65.4 & 98.1 & 166.8 & 317.0 \\
\hline
\end{tabular}


be covered from domestic resources. The scenario regarding the increase of cultivated areas under greenhouses and plastic tunnels is based on the analysis of the evolution of areasundergreenhouses and plastic tunnels, which increased by $50 \%$ from 2007 until 2012 (in 5 years respectively).This would allow and obligate farmers to use selected seeds with high production potential, as well as to correctly apply the technologies, including the procurement of new equipment. Furthermore, production and price volatility resulting from the adverse weather conditions could decrease. With the increase in number of producer groups and organizations the number of storage facilities could also increase and the storage capacity could reach 317 thousand tons in 2021 according to the presented scenario. At the same time, this would also allow for a better production planning, avoiding the surplus production situations for certain species of vegetables or the insufficient cultivation of other species.

\section{CONCLUSION}

The productivity on the vegetables chain is very low, mainly in the primary sector. At the same time, the areas cultivated with vegetables under greenhouses and plastic tunnels increased by about 50\% from 2007 to 2012 . This trend could be also noticed in the case of yields. The proposed scenario shows that starting from the base year 2012 , it is practically possible to bridge up the productivity gaps in about 7 years, on the basis of the increase of areas under greenhouses and plastic tunnels as well as of the increase of yields/ hectare. Cultivation under greenhouses and plastic tunnels permits the use of selected seeds and application of modern technologies. However, this implies the need to improve chain organization, to build up storage facilities and to buy modern logistic systems, in the context of the development of producer groups inclusively. By extrapolation, this scenario can be applyied for other vegetables as well, while the coverage level for the other products is still high even though insufficient, and with a more rigorous chain organization these gaps can be relatively easily recovered. In the European Union, the Common Market Organization provides support to the setting up producer groups and other association forms. While in Netherlands the organization level is $104 \%$, and the EU average is $34 \%$, in Romania the producer organization level is extremely low, under $1 \%$. In order to improve this situation. a solution would be to provide fiscal facilities for the farmers who are organized into producer groups: low VAT rates for the sale of production on common basis or for the procurement of agricultural inputs. The measure is necessary for the diminution of opportunism behaviour in the contractual relations and the improvement of the operation of producer groups (Alboiu, 2012).

At the same time, it is necessary to introduce certain fiscal measures, such as VAT diminution for all the agri-food products and application of a low VAT rate, i.e. from 5 to $9 \%$ for all farmers, regardless of their legal status. A larger tax base could mean not only the increase in number of those who would pay tax, but also the regularization of the commercial behaviour for all players participating to the chain. The producer groups could be also stimulated by the nontaxation of re-invested profits (Alboiu, 2012). In the absence of adequate organization, the increase of yields and obtaining larger productions will not be possible, as it would not enable farmers to obtain high enough incomes to procure and adopt new technologies applied in modern greenhouses and plastic tunnels or to procure modern storage facilities and advanced logistic systems. Hence, the proposed scenario will be feasible on the condition of farmers' organization level improvement and farmers' increased awareness of the importance of collective/association organization role.

\section{REFERENCES}

1. Alboiu C (2012). Collective actions and the dynamic of agrifood system from the perspective of the Romanian small vegetable producers. Producing and reproducing farming systems. New modes of organisation for sustainable food systems of tomorrow. $10^{\text {th }}$ European IFSA Symposium, Aarhus, Denmark, 1-4 July 2012Bardhan, P. (1989). The new institutional economics and development theory: A brief critical assessment. World Development 17(9). 1389-1395.

2. Alboiu C (2012). Governance and contractual structure in the vegetable supply chain in Romania in Romanian Journal of Economic Forecasting, type A, 10/2012, pag. 68-82, ISSN 1993-6788

3. Codron JM, Lemeilleur S (2011). Marketing cooperative vs. commission agent: The Turkish dilemma on the modern fresh fruit and vegetable market. Food Policy. 36 (2). pp. 272-279.

4. Dell'Aquila C, Petriccione G, Perito M (2011). The EU vegetable and fruit sector: overview and post 2013 CAP perspective study. Directorate General for internal 
policies. Policy Department B: Structural and Cohesion Policies. Agriculture and Rural Development. www. europarl.europa.eu/studies

5. Gow H and Swinnen JFM (2007). Up-and downstream restructuring. foreign direct investment. and hold-up problems in agricultural transition. Downloaded from http://erae.oxfordjournals.org/ at INRA Documentation Pierre Bartoli on May 16. 2012

6. Hobbs JE (2006). Markets in metamorphosis: The rise and fall of policy institutions. in G. Van Huylenbroeck. W. Verbeke and L. Lauwers (eds.). Role of institutions in rural policies and agricultural markets. Amsterdam. The Netherlands: Elsevier B.V. 199-212
7. Jacquin E (2010). Aid regime for the fruit \& vegetables sector in the EU: state of play. Bruxelle.

8. Reardon T and Berdegué J (2002). The rapid rise of supermarkets in Latin America

9. Swinnen JFM and Van Herck K (2010). Social Impact of Discount and Organized Food Retail Formats on Remote Regions in Poland. Bulgaria and Romania. Licos Centre For Institutions and Economic Performance. Catholic University Of Leuven (Kul). www.econ.kuleuven.be/licos

10. *** FAO database 2013 